\title{
Macroinvertebrates as tadpole food: importance and body size relationships
}

\author{
Silvia L. Dutra ${ }^{1} \&$ Marcos Callisto ${ }^{1,2}$ \\ ${ }^{1}$ Laboratório de Ecologia de Bentos, Departamento de Biologia Geral, Instituto de Ciências Biológicas, Universidade Federal \\ de Minas Gerais. Caixa Postal 486, 30161-970 Belo Horizonte, Minas Gerais, Brasil. E-mail: sldutra@unb.br \\ 2 Corresponding author. E-mail: callisto@icb.ufmg.br
}

\begin{abstract}
Macroinvertebrates as food were recorded for three anurans tadpoles: Hyla saxicola (Bokermann, 1964) (Hylidae), Scinax machadoi (Bokermann \& Sazima, 1973) (Hylidae), and Bufo rubescens (Lutz, 1925) (Bufonidae). These species are commonly found in the mountain streams at Serra do Cipó National Park, Minas Gerais State, Brazil. Tadpoles were collected in pools of second-order reach in Mascates stream and third and fourth order reaches of Indaiá stream from March-October, 2003. Biometrical data were recorded before dissecting each individual and a feeding importance index was estimated. Eight taxa of chironomids and three taxa of mayfly exuviae were found in the guts, but no significantly differences were found between tadpole species (ANOVA, $\mathrm{p}>0.05)$. The results support the drift transport hypothesis that predicts that tadpoles commonly ingest suspended matter in lotic ecosystems, are generalist feeders, and macroinvertebrates are probably incidental ingested.
\end{abstract}

KEY WORDS. Aquatic food-webs, aquatic insects, conservation, streams, tadpole diet.

RESUMO. Macroinvertebrados como alimento de girinos: importância e relações com tamanho de corpo. A presença de macroinvertebrados como item na dieta de girinos foi estudada para as espécies Hyla saxicola (Bokermann, 1964) (Hylidae), Scinax machadoi (Bokermann \& Sazima, 1973) (Hylidae) e Bufo rubescens (Lutz, 1925) (Bufonidae). Estas espécies são comumente encontradas nos córregos de altitude no Parque Nacional da Serra do Cipó, Estado de Minas Gerais, Brasil. Os girinos foram coletados em poções em um trecho de segunda ordem no córrego Mascates, e em trechos de terceira e quarta ordens no córrego Indaiá, entre março e outubro de 2003. Medidas biométricas foram mensuradas antes da dessecação de cada indivíduo e foi estimado um índice de importância de alimentação para os macroinvertebrados encontrados. Oito taxa de Chironomidae e três taxa de exúvias de Ephemeroptera foram encontrados, mas não houve diferenças significativas entre os macroinvertebrados encontrados nas espécies de girinos (ANOVA, $\mathrm{p}>0,05$ ). Os resultados obtidos corroboram a hipótese de transporte por deriva que prediz que os girinos comumente ingerem partículas orgânicas em suspensão, são generalistas quanto à sua alimentação e os macroinvertebrados são provavelmente ingeridos acidentalmente. PALAVRAS CHAVE. Cadeias alimentares aquáticas, insetos aquáticos, conservação, riachos, dieta de girinos.

Ecosystem destruction is a large threat to biological diversity. The cerrado is an important area of agricultural expansion and is threatened by destruction caused by human activities. For a long time this biome received a low conservation priority, which led to the extinction of many species (Primack \& Rodrigues 2001). Similarly to other taxonomic groups, the amphibians of the cerrado have been severely affected by this human interference (DInIz et al. 2004). Because of their aquatic/terrestrial life cycle, amphibians are exposed to ecological changes in both environments (BRANDÃo \& ARAúJo 2002). Water quality changes caused by insecticides and fertilizers contaminations, drainage of mining areas, and vegetation burns beyond the riparian zones are examples of alterations that can decrease amphibians diversity (ETERovick \& BARRos 2003).
Knowledge about amphibian biology is important to the conservation of the cerrado biome (BRANDÃo \& ARAújo 2002, Diniz et al. 2004). Amphibians are an important energy transfer link between invertebrates and vertebrates (STEBbins \& CoHEN 1995). The decline in amphibian population size in highland tropical sites (Lips et al. 2003) is expected to produce cascading effects throughout aquatic and terrestrial food webs (RANVESTEL et al. 2004).

A tadpole is an energy-gathering, growing, non-reproductive larval stage in the biphasic anuran life cycle (McDiARMID \& Altig 1999). The tropical regions show high anuran diversities and diverse species coexist (Pombal 1997). The importance of resource use in the organization of tadpole communities is still unclear. Some authors assume that food does not play an 
important role in niche partitioning and that habitats are partitioned mainly by space and time (Heyer \& Liem 1976). Others consider species distribution in ponds as a consequence of food availability and influence of feeding strategies among tadpoles of different sizes (Alford \& Crump 1982, Diaz Paniagua 1985, ETERovicK \& Barros 2003).

Tadpoles are usually considered highly specialized, filter-feeding herbivores (Duellman \& Trueb 1986) that ingest planktonic material from the water column, obtain organic materials from pond sediments, or scrape periphyton from submerged substrates. Tadpoles may be classified as opportunistic omnivores or detritivores, and some are opportunistic cannibals (they may feed upon own species eggs) or necrophagous (Summers \& Amos 1997). In general, little is known about their diets and what is ingested/absorbed, and there is a lack of information for tropical species in mountain streams.

Tadpoles can occur in lentic and lotic environments, permanent or temporary, and there is a difference in the use of microhabitats and feeding behavior. Food for tadpoles may often be abundant in temporary ponds (coarse and fine particulated organic matter, and invertebrates exuviae) and larval feeding can exert an important influence on the pond primary production (Seale \& Wassersug 1979). Most tadpole species are benthic, with ventrally located mouths used to feed upon periphyton, detritus, and leaves of aquatic plants (Salthe \& Меснам 1974, Diaz Paniagua 1989). In spite of these general considerations, field studies of tadpole diets are uncommon, and information is scarce, especially for the Neotropics. Flecker et al. (1999) suggested that numerous tadpoles in highland streams, as those we studied at Serra do Cipó, may cause large impacts on benthic processes and communities. Many studies about tadpole diets refer to the ingestion of filamentous algae, debris, and periphyton. Diaz Paniagua $(1985,1989)$ and Arias et al. (2002) found algae and animals in the digestive trait of tadpoles, including protozoa, nematodes, rotiferans and arthropods. Lopez et al. (2002) pointed out the ability of bromeliad ostracods (Elpidium Müller, 1880) to pass unharmed through the Scinax perpusillus (Lutz \& Lutz, 1939) tadpoles gut, being eliminated in the faeces.

The benthic communities are formed by phytobenthos and zoobenthos and their distribution is influenced by such factors as substrate type (pebbles, wood), sediment type (clayish, sandy, organic) and food availability (CALlisto 2000). The benthic macroinvertebrates eat organic debris, algae, and other smaller animals. Considering that scrapping tadpoles forage in the same mesohabitats of benthic macroinvertebrates, the aim of this study was to record macroinvertebrates as food items on tadpole larval diets of Hyla saxicola (Bokermann, 1964) (Hylidae), Scinax machadoi (Bokermann \& Sazima, 1973) (Hylidae), and Bufo rubescens (Lutz, 1925) (Bufonidae), all common species in the streams at Serra do Cipó National Park, southeastern Brazil. The scenario found in Serra do Cipó offers an unique opportunity to test several hypothesis on the tadpole and macroinvertebrates interactions. We tested if bigger tadpoles ingest more macroinvertebrates. The distribution, ecology, and biogeographical aspects of anurans at Serra do Cipó were studied by Eterovick \& Fernandes $(2001,2002)$, Eterovick (2003), Eterovick \& Barros (2003), and Eterovick \& SAZima (2004) but larval diet information is still unknown for this region.

\section{MATERIAL AND METHODS}

This study was carried out from March-October 2003 at Serra do Cipó National Park $\left(19^{\circ} 12^{\prime}-19^{\circ} 20^{\prime} \mathrm{S}, 43^{\circ} 30^{\prime}-43^{\circ} 40^{\prime} \mathrm{W}\right.$, 1,095-1,485 m elevation), southeastern Brazil, Minas Gerais State. The climate has distinct dry and wet seasons, and the rainy season starts in October-November and ends in March (Madeira \& Fernandes 1999).

Tadpoles were collected in backwaters of Indaiá stream (third and fourth order reaches) and in Mascates stream (second-order reach) that ranged in size from 10-40 $\mathrm{m}^{2}$, approximately. These streams show depth variations related to the rainy period in the region but never dry up. All of them have some riffles and backwaters, the bottoms are covered by patches of large pebbles and stones, sandy or silty sediment, with occasional patches of algae or submerged grasses, and fresh, slightly acidic, very oxygenated water. Water temperatures from $8^{\circ} \mathrm{C}$ in July-August to about $22^{\circ} \mathrm{C}$ in January-February. A detailed description of physicochemical features of the study streams can be found in CaLlisto et al. (2005).

Tadpole populations in the stream pools were sampled monthly from April-October 2003. A total of 76 larvae were captured with a hand-net ( $500 \mu \mathrm{m}$ mesh size) at different locations in the pools. The gut contents were preserved in $70 \%$ alcohol. The samples were taken in different hours but always during daylight. The diets of anuran larvae were determined by stereomicroscopical examination of intestinal contents of each preserved larvae.

Body length (BL), tail length (TAL), inter-nostril distance (IND), inter-orbital distance (IOD) and mouth width (MW) were taken for tadpoles, before preservation (Tab. I). Their intestines were also removed and fully examined.

The data analyses was done using food importance index (Ix) that takes into account the frequency (Fr; number of each item found) and the constancy (C; number of tadpoles that contained a specific item; Powel et al. 1990). This index $(\mathrm{Ix}=\{(\mathrm{Fr} / \mathrm{Fr} \%)+(\mathrm{C} / \mathrm{C} \%)\} / 2)$ does not incorporate the item availability in the environment.

Correlation analysis was used to test the hypothesis that bigger tadpoles (morphometric measurements) ingest more macroinvertebrates. The invertebrates are very abundant in the stream bottoms (see CALLISTO et al. 2005) and drift movements transport high diversity of invertebrates (CALlisto \& GoularT 2005). Thus we assume that tadpoles are not selecting their feeding items. Tadpole gut items were compared by ANOVA using the routine Standard test of EcoSim (version 7.22) Software (Gotelli \& ENTSMINGER 2004). 


\section{RESULTS AND DISCUSSION}

Algae and detritus were the most abundant types of food ingested. Among the macroinvertebrates, larvae and exuviae of chironomids and mayfly were found (Tab. II). In most of the tadpole guts we also found a large number of unidentified macroinvertebrates fragments. No significantly differences were found between the tadpole species gut content (ANOVA, $\mathrm{p}>0.05$ ). Probably these fragments belong to dead organisms or exuviae transported by drift (Callisto \& Goulart 2005).

Scinax machadoi tadpoles were collected in Indaiá stream, mainly on rocky substrates and on filamentous algae. The collected tadpoles showed the followed mean measures: Body length $=9.8 \mathrm{~mm}$; tail height $=14.7 \mathrm{~mm}$; mouth width $=3.9 \mathrm{~mm}$. Tadpoles collected on algae showed larger body dimensions than others $(\mathrm{p}<0.05)$ : body length $=10.5 \mathrm{~mm}$; tail height $=16.2 \mathrm{~mm}$; mouth width $=4.2 \mathrm{~mm}$. Chironomid exuviae were common (in total, $\mathrm{Ix}=0.717$ ), and orthocladiins reached up to $\mathrm{Ix}=0.294$. A very small trichopteran larvae was recorded, and it suggests an occasional ingestion. The specimens collected on rocky substrate showed body length $=9.2 \mathrm{~mm}$; tail height $=14.0 \mathrm{~mm}$; mouth width $=3.8 \mathrm{~mm}$. Chironomid exuviae showed, in total, $\mathrm{Ix}=0.678$, while orthocladiins Ix $=0.244$. Some microcrustaceans were found, among them Chydoridae (Cladocera) which showed Ix $=0.033$. Mayfly exuviae were found (Cloeodes Traver, 1938) with Ix $=0.029$.

Hyla saxicola tadpoles collected in Indaiá stream were between rocks at lower depth pools $(<30 \mathrm{~cm})$ with warmer waters due to solar direct incidence: body length $=13.8 \mathrm{~mm}$; tail length $=23.0 \mathrm{~mm}$; mouth width $=4.8 \mathrm{~mm}$. The food items were chironomids (e.g. Thienemanniella sp.) with $\mathrm{Ix}=0.08$. Only two undamaged Orthocladiinae larvae were found, belonging to genus Corynoneura (Winnertz, 1846). Some baetid exuviae were found as food items, Cloeodes (Traver, 1938) and Paracloeodes, Day, 1955, respectively with $\mathrm{Ix}=0.028$ and $\mathrm{Ix}=$ 0.017 , suggesting passive uptake by drift.
Bufo rubescens tadpoles were collected in a big pool at Farofa waterfall on Mascates stream, in a shaded habitat with cobbles and pebbles substrate: body length $=11.9 \mathrm{~mm}$, tail height $=15.4$ $\mathrm{mm}$ and mouth width $=3.4 \mathrm{~mm}$. Hydracarina $(\mathrm{Ix}=0.055)$ and Ostracoda $(\mathrm{Ix}=0.027)$ were important food items in B. rubescens. Chydoridae (Cladocera) ( $\mathrm{Ix}=0.106)$ were also present but at lower frequence. Again, chironomids were the main food item (Ix $=0.426)$. The diet of $B$. bufo (Linnaeus, 1758) was previously studied by SAVAGE (1952) who found algae, planktonic crustaceans and debris, and Harrison (1987), who pointed out that $B$. bufo and Pelodytes punctatus (Daudin, 1802) prefer to feed on planktonic organisms in mid-water. Hyla saxicola tadpoles were collected in three natural puddles near the railway at Mascates stream, but no macroinvertebrates were found in their guts.

There was a positive relationship between body length and tail height, and body length and mouth width for the three studied species (Tab. I). Low correlation values were found between body length and macroinvertebrates, and between mouth size and macroinvertebrates. These data corroborate the occasional ingestion of macroinvertebrates, suggesting that mainly the small tadpoles can use them as food items.

As suggested by Diaz Paniagua (1985), anuran larvae are mostly phytophagous, changing their food habitats and their external and internal morphology at metamorphosis to acquire a more terrestrial body form and a mainly insectivorous diet. The similarity of larval diets among the species is clean from the analysis of intestinal contents. The tadpoles are all basically herbivorous, feeding mostly on algae, debris and eventually supplement their diets with macroinvertebrates that we believed are transported by drift in the water column. The overlap of the feeding resources is frequent in amphibian larval communities (RANVestel et al. 2004). This may be due to the high resource availability in the environment and to the feeding mechanism of amphibian larvae (Diaz Paniagua 1985). The drift transport hypothesis is corroborated by the assumptions proposed by

Table I. Some morphological characteristics $(\mathrm{mm})$ of the tadpole species (median, maximum and minimum values) and correlations values for each species. (BL) Body length, (TAL) tail length, (IND) inter-nostril distance, (IOD) inter-orbital distance, (MW) mouth width.

\begin{tabular}{|c|c|c|c|c|c|c|c|c|c|}
\hline \multirow{2}{*}{ Characteristics } & \multicolumn{3}{|c|}{ Scinax machadoi $(\mathrm{n}=31)$} & \multicolumn{3}{|c|}{ Hyla saxicola $(\mathrm{n}=27)$} & \multicolumn{3}{|c|}{ Bufo rubescens $(n=18)$} \\
\hline & Median & $\min$. & $\max$. & Median & $\min$. & $\max$ & Median & $\min$. & $\max$. \\
\hline $\mathrm{BL}$ & 9.8 & 6.8 & 14.3 & 13.8 & 9.0 & 22.5 & 11.9 & 8.5 & 14.8 \\
\hline TAL & 14.7 & 10.3 & 19.8 & 23.0 & 15.0 & 46.3 & 15.4 & 3.5 & 21.0 \\
\hline IND & 3.1 & 2.3 & 4.4 & 3.3 & 2.0 & 5.0 & 1.9 & 1.5 & 2.2 \\
\hline IOD & 6.1 & 3.8 & 7.3 & 5.9 & 2.0 & 9.0 & 3.1 & 2.4 & 3.5 \\
\hline MW & 3.9 & 2.5 & 5.3 & 4.8 & 2.5 & 7.5 & 3.4 & 2.4 & 3.8 \\
\hline \multicolumn{10}{|l|}{ Correlation values } \\
\hline $\mathrm{BL} \times \mathrm{TAL}$ & 0.8934 & & & 0.6458 & & & 0.6714 & & \\
\hline $\mathrm{BL} \times \mathrm{MW}$ & 0.8137 & & & 0.6613 & & & 0.7656 & & \\
\hline$B L \times$ item & 0.5556 & & & 0.4403 & & & -0.2421 & & \\
\hline MW $x$ item & 0.5246 & & & 0.4090 & & & -0.3278 & & \\
\hline
\end{tabular}


Table II. Importance index (IX values) of food categories on the diets of the studied tadpole species.

\begin{tabular}{|c|c|c|c|c|c|}
\hline & \multicolumn{3}{|c|}{ Scinax machadoi } & \multirow{2}{*}{ Hyla saxicola } & \multirow{2}{*}{ Bufo rubescens } \\
\hline & Indaiá & rocky substrate & algae substrate & & \\
\hline & $\operatorname{Ix}(\mathrm{n}=11)$ & Ix $(n=10)$ & Ix $(n=10)$ & $\mathrm{Ix}(\mathrm{n}=27)$ & Ix $(n=18)$ \\
\hline Unidentified items & 0.186 & 0.192 & 0.180 & 0.421 & 0.376 \\
\hline Cladocera & 0.022 & 0.023 & 0.021 & 0.008 & 0.027 \\
\hline Chydoridae & 0.033 & 0.046 & 0.021 & 0.008 & 0.079 \\
\hline Sididae & 0.000 & 0.000 & 0.000 & 0.008 & 0.000 \\
\hline Diptera, Chironomidae Larvae exuviae & 0.322 & 0.439 & 0.210 & 0.299 & 0.315 \\
\hline Tanypodinae & 0.000 & 0.000 & 0.000 & 0.017 & 0.014 \\
\hline Ablabesmyia & 0.010 & 0.000 & 0.021 & 0.000 & 0.000 \\
\hline \multicolumn{6}{|l|}{ Chironominae } \\
\hline Beardius & 0.000 & 0.000 & 0.000 & 0.008 & 0.000 \\
\hline Dicrotendipes & 0.010 & 0.000 & 0.021 & 0.000 & 0.000 \\
\hline Goeldichironomus & 0.010 & 0.000 & 0.021 & 0.000 & 0.000 \\
\hline Ortocladiinae & 0.244 & 0.194 & 0.294 & 0.053 & 0.033 \\
\hline Corynoneura & 0.010 & 0.000 & 0.021 & 0.025 & 0.000 \\
\hline Cricotopus & 0.010 & 0.000 & 0.021 & 0.017 & 0.000 \\
\hline Thienemanniella & 0.055 & 0.000 & 0.110 & 0.080 & 0.074 \\
\hline Ephemeroptera (exuvia) & 0.022 & 0.023 & 0.021 & 0.000 & 0.000 \\
\hline Baetidae & 0.011 & 0.023 & 0.000 & 0.008 & 0.000 \\
\hline Americabaetis & 0.011 & 0.023 & 0.000 & 0.000 & 0.000 \\
\hline Cloeodes & 0.029 & 0.037 & 0.021 & 0.028 & 0.000 \\
\hline Paracloeodes & 0.000 & 0.000 & 0.000 & 0.017 & 0.000 \\
\hline Hidracarina & 0.000 & 0.000 & 0.000 & 0.000 & 0.055 \\
\hline Ostracoda & 0.000 & 0.000 & 0.000 & 0.000 & 0.027 \\
\hline Trichoptera & 0.010 & 0.000 & 0.021 & 0.000 & 0.000 \\
\hline
\end{tabular}

WASSERSUG (1975) and Altig (1975) that tadpoles commonly ingest suspended matter, including both food and non-food particles, and food selection is only done after the ingestion of the material. They are thus generalists and macroinvertebrates can be ingested eventually. The results corroborate these hypothesis hence the macroinvertebrate food items are the most abundant living organisms in the stream pools. This may be true at least for tadpole communities at Serra do Cipó National Park.

\section{ACKNOWLEDGEMENTS}

Our special thanks to C. Jacobi, R.P. Martins, G.W. Fernandes and M. Moretti for their critical revision of earlier manuscript versions and their valuable suggestions; to P. Eterovick for the identification of the tadpole species and comments; to A. Medeiros for the statistical advise on data analysis. We thank D. Loebmann and U. Caramaschi reviewers who improved the presentation of the manuscript. We also thank the Instituto Brasileiro do Meio Ambiente e dos Recursos Naturais
Renováveis (IBAMA), for permission to work and collect at the Parque Nacional da Serra do Cipó, and for staying overnight at the park house during some of the field excursions. This study was supported by CNPq, FAPEMIG, US Fish \& Wildlife Service.

\section{REFERENCES}

Alford, R.A. \& M.L. Crump. 1982. Habitat partitioning among size classes of larval southern leopard frogs, Rana utricularia. Copeia, Lawrence, 82: 367-373.

Altig, R. 1975. Freeze-drying anuran tadpoles for taxonomic examinations. Herpetological Review, Saint Louis, 6 (1): 13.

Arias, M.M.; P.M. Peltzer \& R.C. Lajmanovich. 2002. Diet of giant tadpole Pseudis paradoxa platensis (Anura, Pseudidae) from Argentina. Phyllomedusa, Belo Horizonte, 1 (2): 97-100.

BRANDÃo, R.A. \& A.F.B. ARAúJo. 2002. A herpetofauna associada a matas de galeria no Distrito Federal, p. 560-604. In: Cerrado: caracterização e recuperação de matas de galeria. Planaltina, EMBRAPA/CPAC, 899p. 
Callisto, M. 2000. Macroinvertebrados bentônicos, p. 141-151, In: Lago Batata: impacto e recuperação de um ecossistema amazônico. Rio de Janeiro, Universidade Federal do Rio de Janeiro, 342p.

Callisto, M.; M. Goulart; A.O. Medeiros; P. Moreno \& C.A. Rosa. 2005. Diversity assessment of benthic macroinvertebrates, yeasts and microbiological indicators along a longitudinal gradient in Serra do Cipó, Brazil. Brazilian Journal of Biology, Rio de Janeiro, 64 (4): 743-755.

Callisto, M. \& M.D. Goulart. 2005. Invertebrate drift along a longitudinal gradient in a Neotropical stream in Serra do Cipó National Park, Brazil. Hydrobiologia, New York, 539: 47-56.

Diaz Paniagua, C. 1985. Larval diets related to morphological characters of five anuran species in the Biological Reserve of Doñana (Huelva, Spain). Amphibia Reptila, Leiden, 6: $307-$ 322.

Diaz Paniagua, C. 1989. Larval diets of two anuran species, Pelodytes punctatus and Bufo bufo, in SW Spain. Amphibia Reptila, Leiden, 10: 71-75.

Diniz, J.A.F.; L.M. BinI; C.M. Vieira; M.C. DE Souza; R.P. Bastos; D. Brandão \& L.G. Oliveira. 2004. Spatial patterns in species richness and priority areas for conservation of anurans in the cerrado region. Amphibia Reptila, Leiden, 25 (1): 63-75.

Duellman W.E. \& L. TRueb. 1986. Biology of Amphibians. New York, Mc Graw-Hill Book Company, 670p.

Eterovick, P.C. 2003. Distribution of anuran species among montane streams in south-eastern Brazil. Journal of Tropical Ecology, New York, 19: 219-228.

Eterovick, P.C. \& I.S. Barros. 2003. Niche occupancy in southeastern Brazilian tadpole communities in montane-meadow streams. Journal of Tropical Ecology, New York, 19: 439-448.

Eterovick, P.C. \& G.W. Fernandes. 2001. Tadpole distribution within montane meadow streams at the Serra do Cipó, southeastern Brazil: ecological or phylogenetic constraints? Journal of Tropical Ecology, New York, 17: 683-693.

Eterovick, P.C. \& G.W. Fernandes. 2002. Why do breeding frogs colonize some puddles more than others? Phyllomedusa, Belo Horizonte, 1 (1): 31-40.

Eterovick, P.C.; I. Sazima. 2004. Anfíbios da Serra do Cipó, Minas Gerais. Belo Horizonte, Editora PUC Minas Gerais, 152p.

Flecker, A.S.; B.P. Feifarek \& B.W. Taylor. 1999. Ecosystem engineering by a tropical tadpole: density-dependent effects on habitat structure and larval growth rates. Copeia, Lawrence, 1999: 495-500.

Gotelli, N.J. \& G.L. EnTSminger. 2004. EcoSim: Null models software for ecology. Version 7, Acquired Intelligence Inc. \& Kesey-Bear. Jericho, VT 05465. Available on line at http:/ /garyentsminger.com/ecosim/index.htm.

HaRrison, J.D. 1987. Food and feeding relations of common frog and common toad tadpoles (Rana temporaria and Bufo bufo) at a pond in Mid-Wales. Herpetological Journal, London, 1: 141-143.

Heyer, W.R. \& D.S. LIEM. 1976. Analysis of the intergeneric relationships of the Australian frog family Myobatrachidae. Smithsonian Contributions to Zoology, Washington, 233: 1-29.

Lips, K.R.; J.D. Reeve \& L.R. Witters. 2003. Ecological traits predicting amphibians population declines in Central America. Conservation Biology, New York, 13: 117-125.

Lopez, L.C.S.; D.A. Gonçalves; A. Mantovani \& R.I. Rios. 2002. Bromeliad ostracods pass through amphibian (Scinax perpusillus) and mammalian guts alive. Hydrobiologia, New York, 405: 209-211.

Madeira, J.A. \& G.W. Fernandes. 1999. Reproductive phenology of sympatric taxa of Chamaecrista (Leguminosae) in Serra do Cipó, Brazil. Journal of Tropical Zoology, Firenze, 15: 463-479.

McDiarmid, R.W. \& R. Altig. 1999. Tadpoles: The biology of anuran larvae. Chicago, The University of Chicago Press, $\mathrm{X}+444 \mathrm{p}$.

Pombal JR., J.P. 1997. Distribuição espacial e temporal de anuros (Amphibia) em uma poça permanente na Serra de Paranapiacaba, Sudeste do Brasil. Brazilian Journal of Biology, Rio de Janeiro, 57 (4): 583-594.

Powel,R.; S.A. Maxey \& J.H. Greve. 1990. The occurrence of Terranova caballeroi (Nematoda: Ascarididae) on Antillophis parvifrons protenus (Serpentes: Colubridae) from Hispaniola. Caribbean Journal of Sciences, Puerto Rico, 26: 72.

Primack, R.B. \& E. Rodrigues. 2001. Biologia da Conservação. Londrina, Ed. Primack, 328p.

Ranvestel, A.W.; K.R. Lips; C.M. Pringle; M.R. Whiles \& R.J. Bixby. 2004. Neotropical tadpoles influence stream benthos: evidence for the ecological consequences of decline amphibian populations. Freshwater Biology, New York, 49: 274-285.

Salthe, S.N. \& J.S. Меснам. 1974. Reproductive courtship patterns, p. 309-521, In: B. Lofts (Ed.). Physiology of the Amphibia. New York, Academic Press, 750p.

SAVAGE, R.M. 1952. Ecological, physiological, and anatomical observations of some species of anuran tadpoles. Proceedings of Zoological Society of London, London, 122: 467-514.

SeAle, D.B. \& R.J. Wassersug. 1979. Suspension feeding dynamics of anuran larvae related to their functional morphology. Oecologia, New York, 39: 259-272.

Stebbins, R.C. \& N.W. Cohen. 1995. A Natural History of Amphibians. New Jersey, Princeton University Press, 316p.

Summers, K. \& W. Amos. 1997. Behavioral, ecological, and molecular genetic analyses of reproductive strategies in the Amazonian dart-poison frog, Dendrobates ventrimaculatus. Behavioral Ecology, Oxford, 8: 260-267

WASSERSug R.J. 1975. The adaptive significance of the tadpole stage with comments on the maintenance of complex life cycles in anurans. American Zoologist, Seattle, 15: 405-417.

Received in 30.VIII.2005; accepted in 07.X.2005. 